Юрчик Г. М. [1; ORCID ID: 0000-0003-1013-6940], к.е.н., доцент,

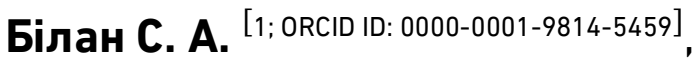
к.п.н., доцент

${ }^{1}$ Національний університет водного господарства та природокористування, м. Рівне

\title{
СОЦІАЛЬНІ ВИДАТКИ В УКРӒ̈НІ: СТРУКТУРНО-ДИНАМІЧНІ ОСОБЛИВОСТІ ФІНАНСУВАННЯ ТА ВПЛИВ НА СОЦІАЛЬНУ БЕЗПЕКУ
}

Досліджено структурно-динамічні особливості державного фінансування видатків соціального призначення В Україні. Виявлено значимість різних рівнів бюджетної системи та окремих джерел у фінансуванні соціальної сфери. Обґрунтовано вплив видатків соціального призначення на рівень соціальної безпеки та його основні складові в Україні.

Ключові слова: соціальні видатки; соціальна безпека; соціальна сфера; бідність; рівень життя.

Вступ. Основний Закон визначає Україну соціальною державою, політика якої спрямована на створення умов для забезпечення належного рівня життя, людського розвитку та соціальної безпеки. Це потребує усунення або ж мінімізації факторів соціального ризику, нейтралізації та обмеження потенційно деструктивної в соціальному аспекті природи ринку. Тобто реалізація соціальної функції держави потребує регуляторного впливу на всіх рівнях, що не можливе без відповідного фінансового забезпечення. Загострення соціальних ризиків обумовлює зростання значимості держави як суб'єкта фінансування соціальної сфери, що включає не лише кошти зведеного державного бюджету (ЗДБ), але державних позабюджетних Фондів соціального страхування (ФСС). Відтак, питання дослідження структурно-динамічних особливостей фінансування соціальної сфери в Україні в цілях підвищення їх ефективності в умовах обмеженості бюджетних ресурсів та макроекономічної нестабільності $€$ актуальним.

Аналіз останніх досліджень. Посилення уваги до проблем фінансування соціальних видатків в умовах загострення соціальних викликів були і залишаються в центрі наукових досліджень. Варто відмітити наукові доробки у відповідній сфері В. Андрущенко,
О. Василик,
О. Величко,
А. Гальчинського,
В. Геєць,
М. Карліна, 
А. Мельник, Г.Ляхович, В. Опаріна, В.Козак, В.Кравченко та ін. Проте, питання дослідження сучасних структурно-динамічних особливостей фінансування соціальної сфери в Україні потребують подальших розробок, оскільки в національних реаліях наявні значні ризики соціальній безпеці, а пошук шляхів підвищення ефективності фінансування соціальних видатків відбувається в умовах обмеженості бюджетних ресурсів.

Постановка завдання. 3 огляду на це, метою даної статті $\epsilon$ дослідження структурно-динамічних особливостей державного фінансування видатків соціального призначення в Україні у контексті їх впливу на соціальну безпеку.

Наукові результати. Кінцевою метою фінансування соціальної сфери $\epsilon$ не лише забезпечення матеріального добробуту, а й задоволення духовних потреб, охорона здоров'я, які комплексно інтегруються в поняття соціальної безпеки (СБ).

Дослідження бюджетного фінансування видатків соціального призначення (табл. 1) свідчить, що протягом 2014-2020 рр. їх обсяг невпинно зростав. Так, якщо у 2014 р. фінансування соціальних видатків зі зведеного державного бюджету складало 309,1 млрд грн, то у 2020 р. - 1149,6 млрд. Нарощення соціальних видатків відбувалося і за всіма їх складовими статтями - охорона здоров'я, духовний та фізичний розвиток, освіта, соціальний захист та соціальне забезпечення.

Таблиця 1

Динаміка показників бюджетного фінансування видатків соціального призначення, 2014-2020рр. [1]

\begin{tabular}{|c|c|c|c|c|c|c|c|c|c|c|}
\hline \multirow{4}{*}{ Роки } & \multicolumn{10}{|c|}{ Видатки соціального призначення } \\
\hline & \multicolumn{2}{|c|}{ всього } & \multicolumn{8}{|c|}{ в тому числі: } \\
\hline & \multirow{2}{*}{$\begin{array}{l}\frac{1}{2} \\
\text { 는 } \\
\text { 돈 } \\
\frac{0}{5}\end{array}$} & \multirow{2}{*}{ 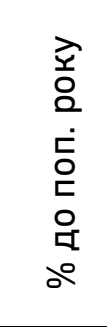 } & \multicolumn{2}{|c|}{$\begin{array}{l}\text { охорона } \\
\text { здоров'я }\end{array}$} & \multicolumn{2}{|c|}{$\begin{array}{c}\text { духовний та } \\
\text { фізичний } \\
\text { розвиток }\end{array}$} & \multicolumn{2}{|c|}{ освіта } & \multicolumn{2}{|c|}{$\begin{array}{c}\text { соціальний захист } \\
\text { та соціальне } \\
\text { забезпечення }\end{array}$} \\
\hline & & & $\begin{array}{l}\text { 든 } \\
\text { 당 } \\
\frac{0}{5} \\
\frac{5}{2}\end{array}$ & 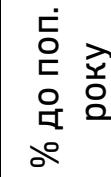 & $\begin{array}{l}\text { 존 } \\
\text { 는 } \\
\text { 동 } \\
\frac{}{5}\end{array}$ & 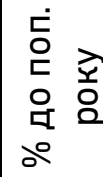 & $\begin{array}{l}\frac{1}{2} \\
\text { 는 } \\
\text { 당 } \\
\frac{0}{5}\end{array}$ & 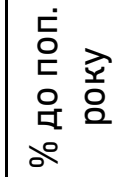 & $\begin{array}{l}\text { 즌 } \\
\text { 은 } \\
\text { 뜽 } \\
\frac{5}{\Sigma}\end{array}$ & 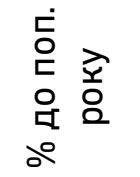 \\
\hline 2014 & 309,1 & - & 57.2 & - & 13,9 & - & 100,1 & - & 138 & - \\
\hline 2015 & 377,7 & 122,2 & 71,0 & 124,2 & 16,2 & 117,1 & 114,2 & 114,1 & 176,3 & 127,7 \\
\hline 2016 & 480,2 & 127,1 & 75,5 & 106,3 & 16,9 & 104,1 & 129,4 & 113,3 & 258,3 & 146,5 \\
\hline 2017 & 590,4 & 123,0 & 102,4 & 135,6 & 24,3 & 144,1 & 177,9 & 137,5 & 285,8 & 110,6 \\
\hline 2018 & 664,2 & 112,5 & 115,9 & 113,1 & 29,0 & 119,1 & 210,0 & 118,1 & 309,4 & 108,3 \\
\hline 2019 & 720,5 & 108,5 & 128,4 & 110,8 & 31,6 & 108,8 & 238,8 & 113,7 & 321,8 & 104,0 \\
\hline 2020 & 806,5 & 111,9 & 175,8 & 136,9 & 31,7 & 100,5 & 252,3 & 105,7 & 346,7 & 107,7 \\
\hline
\end{tabular}

Попри це, все ж можна констатувати, що в останні роки темпи 
зростання обсягів фінансування соціальних видатків суттєво зменшились (якщо у 2015-2017 рр. щорічний приріст видатків варіювався від 22,2 до 27,1\%, то у 2018-2020 рр. - від 8,5 до 12,5\%). Єдина стаття соціального спрямування, приріст фінансування якої у 2020 р. суттєво збільшився, є охорона здоров'я $(36,9 \%)$, що пов'язано з інфекційними викликами.

Очевидно, що аналіз обсягів фінансування соціальних видатків в номінальному виразі не відображає об'єктивної дійсності з огляду на значний рівень інфляції. В цілях підвищення об'єктивності аналізу доцільно порівняти темпи зростання соціальних видатків 3 приростом індексу споживчих цін (рис. 1). Показово, що протягом 2015-2020 рр., попри номінальне зростання обсягів фінансування соціальної сфери, все ж відповідні темпи не відповідали збереженню їх реальної купівельної спроможності, оскільки були суттєво нижчими ніж приріст цін.

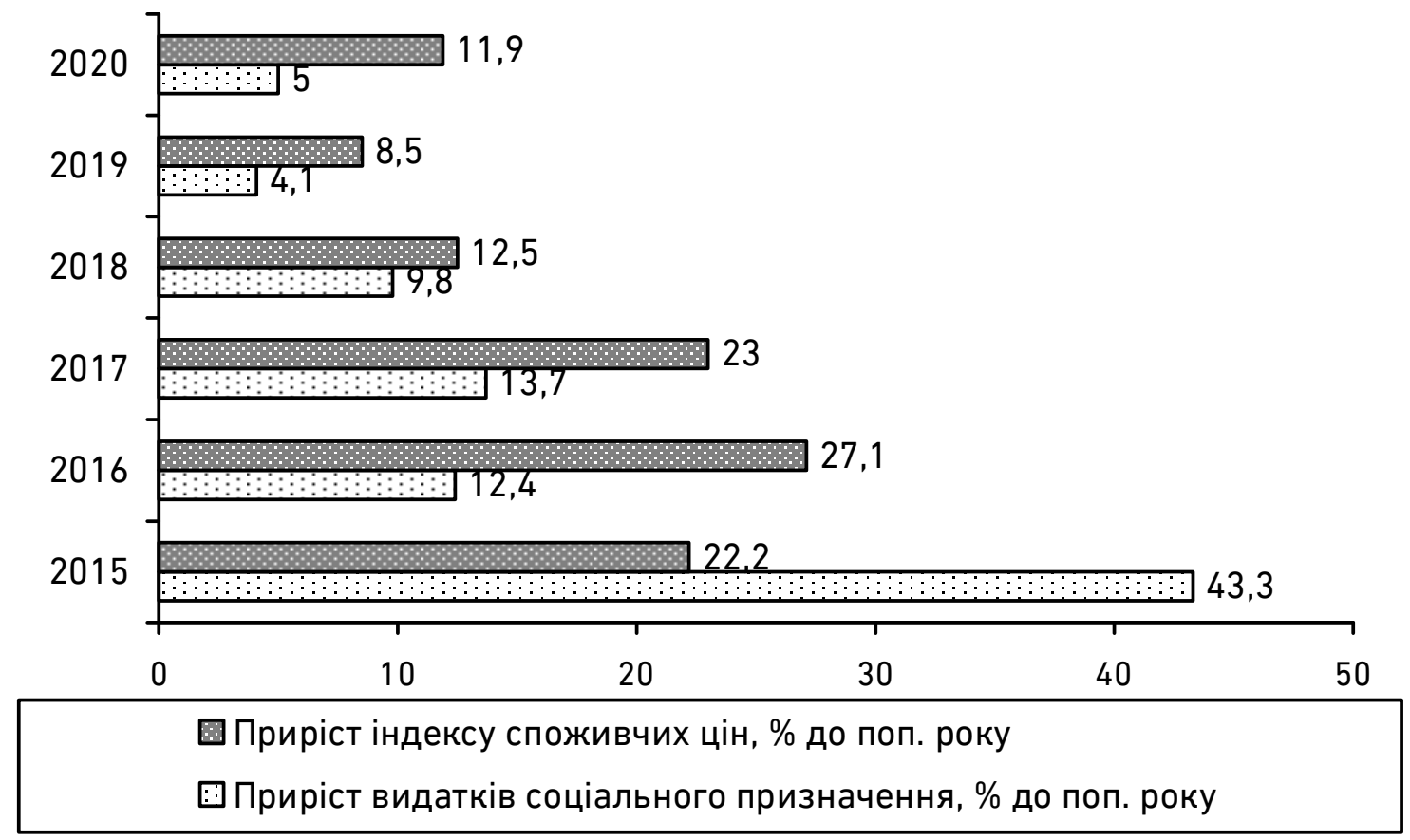

Рис. 1. Темпи зростання бюджетного фінансування соціальних видатків та індексу споживчих цін в Україні, 2015-2020рр. [1]

Так, у 2015 р. приріст інфляції склав 43,3\%, тоді як приріст соціальних видатків в номінальному вираженні - 22,2\%, у 2016 р. ці ж темпи склали відповідно 27,1\% та 12,4\%. Таке ж співвідношення на користь темпів інфляції було збережено протягом 2017-2020 рр., тобто, на жаль, фінансування соціальних видатків в Україні в реальному вираженні не підтримується протягом цілого ряду років.

Дослідження фінансування соціальних видатків за рівнями бюджетної системи в Україні (табл. 2) свідчить про різну соціальну відповідальність державного та місцевих бюджетів. 
Таблиця 2

Бюджетне фінансування видатків соціального призначення за рівнями бюджетної системи в Україні, 2014-2020 рр. [1; 4]

\begin{tabular}{|c|c|c|c|c|c|}
\hline \multirow[b]{2}{*}{ Роки } & \multirow[b]{2}{*}{ Бюджет } & \multicolumn{4}{|c|}{ Видатки за функціональним призначенням, \% до всього } \\
\hline & & $\begin{array}{l}\text { охорона } \\
\text { здоров'я }\end{array}$ & $\begin{array}{c}\text { духовний та } \\
\text { фізичний розвиток }\end{array}$ & освіта & $\begin{array}{c}\text { соціальний захист та } \\
\text { соціальне забезпечення }\end{array}$ \\
\hline \multirow{3}{*}{2014} & ДБ* & 3,5 & 1,6 & 9,6 & 26,9 \\
\hline & MБ & 20,8 & 4,0 & 32,0 & 25,7 \\
\hline & ЗДБ & 10,9 & 2,6 & 19,1 & 26,4 \\
\hline \multirow{3}{*}{2015} & ДБ & 2,8 & 1,6 & 7,5 & 25,7 \\
\hline & MБ & 21,5 & 3,5 & 30,3 & 26,2 \\
\hline & ЗДБ & 10,4 & 2,4 & 16,8 & 25,9 \\
\hline \multirow{3}{*}{2016} & ДБ & 2,5 & 1,0 & 7,1 & 31,0 \\
\hline & MБ & 18,2 & 3,4 & 27,3 & 30,7 \\
\hline & ЗДБ & 9,0 & 2,0 & 15,5 & 30,9 \\
\hline \multirow{3}{*}{2017} & ДБ & 3,0 & 1,4 & 7,3 & 25,5 \\
\hline & MБ & 17,5 & 3,4 & 27,9 & 28,8 \\
\hline & ЗДБ & 9,7 & 2,3 & 16,8 & 27,0 \\
\hline \multirow{3}{*}{2018} & ДБ & 3,3 & 1,5 & 6,5 & 23,9 \\
\hline & MБ & 16,6 & 3,4 & 29,4 & 25,8 \\
\hline & ЗДБ & 9,3 & 2,3 & 16,8 & 24,7 \\
\hline \multirow{3}{*}{2019} & ДБ & 4,7 & 1,2 & 6,3 & 26,8 \\
\hline & ME & 16,1 & 3,9 & 33,6 & 18,5 \\
\hline & ЗДБ & 9,4 & 2,3 & 17,4 & 23,4 \\
\hline \multirow{3}{*}{2020} & ДБ & 11,1 & 0,9 & 4,7 & 28,6 \\
\hline & MБ & 10,9 & 4,7 & 42,7 & 5,1 \\
\hline & ЗДБ & 11,0 & 2,0 & 15,8 & 21,7 \\
\hline
\end{tabular}

* Умовні позначення: ДБ - державний бюджет, МБ - місцевий бюджет, ЗДБ зведений державний бюджет.

Так, найбільша частка видатків соціального спрямування місцевих бюджетів, яка протягом 2014-2020 рр. суттєво зросла, припадає на освіту (у 2014 р. - 32\%, у 2020 р. - 42,7\%). Водночас значимість державного бюджету у фінансуванні освіти є суттєво нижчою та невпинно зменшується (у 2014 р. - 9,6\%, у 2020 р. - 4,7\%). Таким чином, відповідальність за фінансування сфери освіти переважно покладається на місцеві органи влади за посередництвом відповідних бюджетів. Показово, що відповідальність органів місцевої влади щодо фінансування охорони здоров'я протягом 2014-2020 рр. суттєво знизилась (з 20,8\% у 2014 р. до $10,9 \%$ - у 2020 р.).

Натомість навантаження на державний бюджет щодо фінансування охорони здоров'я суттєво збільшилось (з 3,5\% у 2014 р. до $11,1 \%$ у 2020 р.), тобто протягом 2014-2020рр. відбулась структурна трансформація фінансування сфери охорони здоров'я за рівнями бюджетної системи, яка зумовила практично однакове фінансове навантаження на державний $(11,1 \%)$ та місцеві $(10,9 \%)$ 
бюджети. Варто зауважити, що незмінним та первинним пріоритетом державного бюджету $\epsilon$ фінансування соціального захисту та забезпечення населення (24-31\% протягом 2014-2020 рр.). Водночас значимість місцевих бюджетів щодо фінансування програм соціального захисту у 2020 р. суттєво знизилась.

Окрім зведеного державного бюджету, важливим джерелом фінансування видатків соціального призначення $€$ Фонди соціального страхування. 3 огляду на запровадження загальнообов'язкового державного соціального страхування, в цілях підвищення об'єктивності аналізу слід враховувати і обсяги фінансування видатків соціального призначення 3 цільових державних страхових фондів (рис. 2).

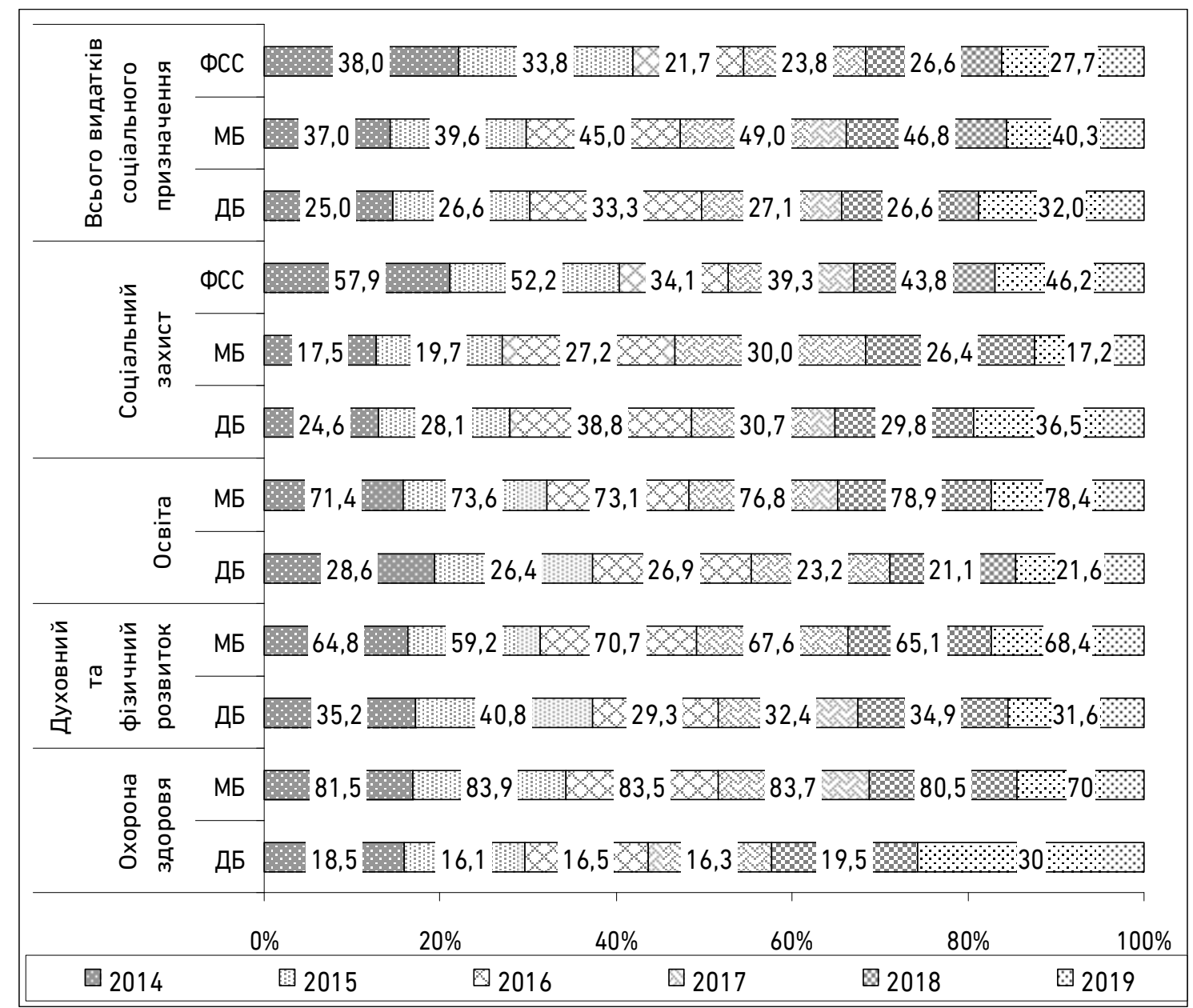

Рис. 2. Структура видатків соціального призначення за джерелами фінансування в Україні, 2014-2019рр., \% до всього видатків відповідного призначення $[1 ; 4 ; 5]$

Умовні позначення: ФСС - фонди соціального страхування; ДБ - державний бюджет, МБ - місцевий бюджет.

Комплексний аналіз структури фінансування соціальної сфери за основними джерелами свідчать, що найбільша частка видатків 
соціального призначення припадає на місцеві бюджети (протягом 2014-2019 рр. відповідна частка варіювала в межах від 37 до 49\%). Значимість державного бюджету у фінансуванні соціальної сфери $\epsilon$ також досить високою (25-32\%) та протягом 2014-2019 рр. його значимість зросла. Натомість значимість фондів соціального страхування у фінансуванні видатків соціального призначення дещо знизилась (з 38\% у 2014 р. до $28 \%$ у 2019 р.). Попри це, все ж страхові фонди $€$ значимим джерелом фінансування соціальної сфери в Україні. Аналогічний напрям дослідження за окремими статтями видатків соціального призначення доводить факт дуже високої значимості фондів соціального страхування та державного бюджету у фінансуванні соціального захисту і забезпечення населення (у 2019 р. відповідні частки складали 46,2\% та 36,5\%). Водночас питома вага видатків на соціальний захист, що фінансуються 3 місцевих бюджетів, $€$ суттєво нижчою $(17,2 \%$ у 2019 р.). Показово, що більшість видатків на освіту, охорону здоров'я та духовний і фізичний розвиток фінансуються з місцевих бюджетів (65-80\%).

Порівняння загальних обсягів державного фінансування видатків соціального призначення в Україні та ЄС по відношенню до ВВП (табл. 4) демонструє вищий рівень соціальної спрямованості державної політики $Є$ С.

Показово, що частка бюджетних видатків соціального призначення по відношенню до ВВП в Україні $€$ суттєво вищою порівняно з ЄC (у 2019 р. складала відповідно 18,1\% проти 12,3\%). Однак, з урахуванням Фондів соціального страхування загальна частка соціальних видатків у відсотках до ВВП в ЄС є суттєво вищою (у 2019 р. складала 31,5\% проти 25,1\% в Україні). Видатки на соціальний захист та забезпечення по відношенню до ВВП у 2014 р. в Україні були на 1,3\% вищими ніж в ЄС. Водночас з 2015 по 2019 р. дане співвідношення незмінно є суттєво вищим в ЄС. Очевидно, що частка видатків на освіту $€$ незмінно вищою в Україні, а на охорону здоров'я - в ЄС, на духовний та фізичний розвиток - практично однаковою з незначним переважанням в $Є C$.

Дослідження масштабів та структурно-динамічних особливостей фінансування соціальних видатків $\epsilon$ необхідною передумовою для виявлення їх впливу на соціальну безпеку та іï індикатори.

Розрахунок рівня соціальної безпеки в Україні здійснює Міністерство розвитку економіки, торгівлі та сільського господарства як складової економічної безпеки. Як свідчать дані (табл. 4), рівень соціальної безпеки в Україні є достатньо низьким (протягом 2010- 
2019 рр. варіював від 56 до 64\%). Показово, що протягом 20142015 рр. він суттєво знизився і лише окреслив тенденцію до зростання з 2017 року.

Таблиця 3

Обсяги бюджетного та страхового фінансування видатків соціального призначення (\% до ВВП) в Україні та ЄС, 2014-2019 рр.

$[1 ; 3 ; 4 ; 5]$

\begin{tabular}{|c|c|c|c|c|c|c|c|c|c|c|}
\hline \multirow{2}{*}{ Роки } & \multicolumn{2}{|c|}{$\begin{array}{c}\text { всього видатків } \\
\text { соціального } \\
\text { призначення, \% до ВВП }\end{array}$} & \multicolumn{2}{|c|}{$\begin{array}{c}\text { охорона } \\
\text { здоров'я, \% до } \\
\text { ВВП } \\
\end{array}$} & \multicolumn{2}{|c|}{$\begin{array}{c}\text { духовний та } \\
\text { фізичний розвиток, } \\
\% \text { до ВВП }\end{array}$} & \multicolumn{2}{|c|}{$\begin{array}{c}\text { освіта, } \% \\
\text { до ВВП }\end{array}$} & \multicolumn{2}{|c|}{$\begin{array}{c}\text { соціальний захист } \\
\text { та забезпечення, } \\
\% \text { до ВВП } \\
\end{array}$} \\
\hline & \begin{tabular}{|c} 
бюджетні \\
видатки \\
(БВ)
\end{tabular} & \begin{tabular}{|c|} 
бюджетні та \\
страхові \\
видатки (БСВ) \\
\end{tabular} & БВ & БСВ & БВ & БСВ & БВ & БСВ & БВ & БСВ \\
\hline \multicolumn{11}{|c|}{ Україна } \\
\hline 2014 & 19,5 & 31,4 & 3,6 & 3,6 & 0,9 & 0,9 & 6,3 & 6,3 & 8,7 & 20,6 \\
\hline 2015 & 19,0 & 28,7 & 3,6 & 3,6 & 0,8 & 0,8 & 5,7 & 5,7 & 8,9 & 18,5 \\
\hline 2016 & 20,1 & 25,7 & 3,2 & 3,2 & 0,7 & 0,7 & 5,4 & 5,4 & 10,8 & 16,4 \\
\hline 2017 & 19,8 & 26,0 & 3,4 & 3,4 & 0,8 & 0,8 & 6,0 & 6,0 & 9,6 & 15,8 \\
\hline 2018 & 18,7 & 25,4 & 3,3 & 3,3 & 0,8 & 0,8 & 5,9 & 5,9 & 8,7 & 15,4 \\
\hline 2019 & 18,1 & 25,1 & 3,2 & 3,2 & 0,8 & 0,8 & 6,0 & 6,0 & 8,1 & 15,0 \\
\hline \multicolumn{11}{|c|}{$\epsilon C$} \\
\hline 2014 & 13,0 & 32,5 & 2,4 & 7,2 & 0,4 & 1,1 & 2,8 & 4,9 & 7,4 & 19,3 \\
\hline 2015 & 13,1 & 32,0 & 2,5 & 7,2 & 0,4 & 1,0 & 2,8 & 4,8 & 7,4 & 19,0 \\
\hline 2016 & 12,9 & 32,0 & 2,5 & 7,1 & 0,4 & 1,1 & 2,7 & 4,8 & 7,3 & 19,0 \\
\hline 2017 & 12,5 & 31,6 & 2,4 & 7,1 & 0,4 & 1,1 & 2,6 & 4,7 & 7,1 & 18,7 \\
\hline 2018 & 12,3 & 31,4 & 2,4 & 7,0 & 0,4 & 1,1 & 2,6 & 4,7 & 6,9 & 18,6 \\
\hline 2019 & 12,3 & 31,5 & 2,4 & 7,1 & 0,4 & 1,1 & 2,6 & 4,7 & 6,9 & 18,6 \\
\hline
\end{tabular}

Умовні позначення: БВ - бюджетні видатки (включають видатки зведеного державного бюджету); БСВ - бюджетні та страхові видатки (включають видатки зведеного державного бюджету та Фондів загальнообов'язкового державного соціального страхування).

Таблиця 4

Динаміка індексу соціальної безпеки та його зв'язок з показниками фінансування соціальних видатків в Україні, 2010-2019 рр. [1; 2; 4]

\begin{tabular}{|c|c|c|c|}
\hline \multirow{2}{*}{ Роки } & $\begin{array}{c}\text { Індекс } \\
\text { соціальної } \\
\text { безпеки, \% }\end{array}$ & $\begin{array}{c}\text { Частка бюджетних } \\
\text { видатків соціального } \\
\text { призначення, \% до ВВП }\end{array}$ & $\begin{array}{c}\text { Частка бюджетних та страхових } \\
\text { видатків соціального } \\
\text { призначення, \% до ВВП }\end{array}$ \\
\hline 2010 & $\mathrm{X}$ & $\mathrm{Y1}$ & Ү2 \\
\hline 2011 & 59 & 22,3 & 35,8 \\
\hline 2012 & 64 & 19,3 & 32,6 \\
\hline 2013 & 62 & 21,3 & 34,9 \\
\hline 2014 & 57 & 22,2 & 35,4 \\
\hline 2015 & 55 & 19,5 & 30,3 \\
\hline 2016 & 56 & 19,0 & 28,5 \\
\hline 2017 & 59 & 20,1 & 25,7 \\
\hline 2018 & 60 & 19,8 & 26,0 \\
\hline 2019 & 60 & 18,7 & 25,4 \\
\hline Коефіцієнт кореляції & 18,1 & 25,1 \\
\hline
\end{tabular}


Як свідчать розрахунки, між часткою видатків соціального призначення та індексом соціальної безпеки хоча наявний не достатньо щільний зв'язок, проте він $€$ прямим, тобто зростання обсягів фінансування соціальної сфери $€$ фактором зростання соціальної безпеки.

Оскільки поняття соціальної безпеки є інтегральним та таким, що включає цілий ряд інших показників, необхідно дослідити наявність зв'язку між рівнем соціальної безпеки та окремими їі показниками-індикаторами (табл. 5). Як свідчить кореляційний аналіз, отримані результати $€$ досить суперечливими. Зокрема, виявлено щільний зв'язок між загальними соціальними видатками (\% до ВВП) та видатками на охорону здоров'я та освіту (\% до ВВП) як складовими соціальної безпеки, що є цілком закономірним. В той же час, показники фінансування соціальних видатків демонструють наявність досить щільного та зворотного зв'язку між відношенням середньої заробітної плати до прожиткового мінімуму, що певною мірою суперечить логіці. Однак, в дійсності в умовах, коли законодавчо встановлений прожитковий мінімум $€$ критично заниженим ${ }^{1}$, відповідний індикатор соціальної безпеки не може об'єктивно відображати реальний зв'язок та закономірність зміни. Показники захворюваності також демонструють суперечливий зв'язок 3 обсягами фінансування соціальних видатків, адже слідуючи логіці проведених розрахунків збільшення видатків соціального призначення по відношенню до ВВП супроводжується збільшенням показників захворюваності. Це скоріше доводить той факт, що основним фактором поширення таких хвороб, як ВІЛінфекція та туберкульоз є спосіб та рівень життя населення, що не формуються моментно, виходячи з фінансування соціальної сфери. Практично єдиним показником-індикатором соціальної безпеки, який демонструє досить щільний та логічний зв'язок з обсягами фінансування соціальних видатків, $€$ рівень зайнятості населення (зростання рівня зайнятості населення $є$ фактором зростання соціальних видатків).

Загалом, можна констатувати, що дослідження впливу соціальних видатків на показники-індикатори соціальної безпеки (відповідно до національної методики оцінювання економічної безпеки) в переважній більшості не демонструють логічного та щільного зв'язку з показниками фінансування соціальної сфери, проте це не означає, що такого впливу немає.

${ }^{1}$ Цей факт визнає Міністерство соціальної політики України, яке поряд з поняттям законодавчого прожиткового мінімуму здійснює моніторинг так званого фактичного прожиткового мінімуму, рівень якого порівняно з першим $є$ практично вдвічі вищим. 


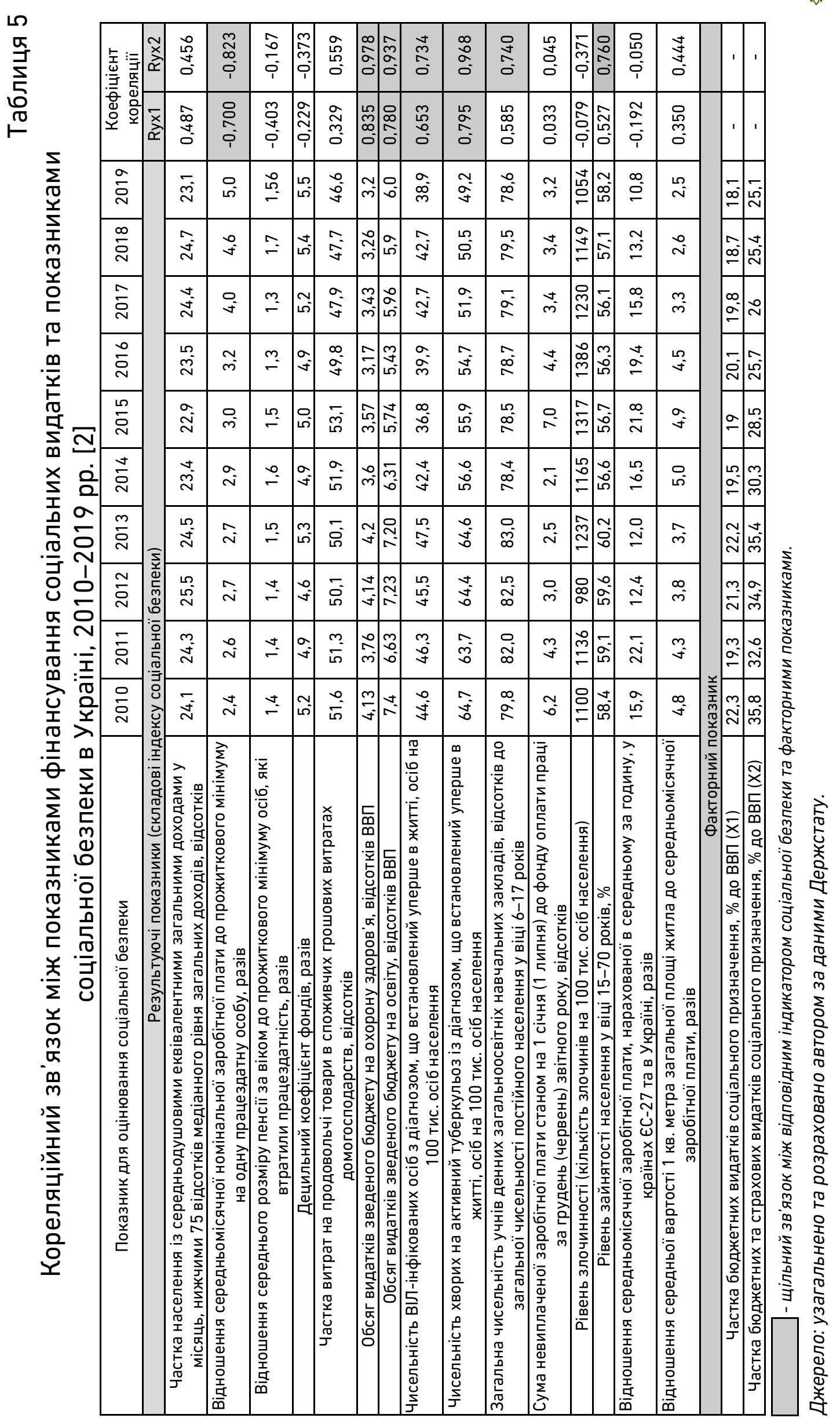


Адже перелік показників-індикаторів, на базі яких розраховується рівень соціальної безпеки відповідно до національної методики, є чітко визначеним та таким, що не завжди відображає поточний вплив, а може виявлятися через тривалий часовий лаг або ж комплексно разом з іншими показниками. 3 огляду на це, нами було сформовано вибірку інших соціальних показників та оцінено вплив на них видатків соціального призначення (табл. 6). Розрахунки доводять, що обсяги фінансування соціальних видатків чинять однозначно позитивний вплив на демографічні показники. Водночас рівень бідності населення не демонструє наявності тісного зв'язку з показниками фінансування соціальної сфери (з огляду на це, можна констатувати, що бідність населення в більшій мірі визначається іншими факторами, в тому числі - макроекономічними).

Таблиця 6

Кореляційний аналіз впливу видатків соціального призначення

(у \% до ВВП) на основні соціальні індикатори в Україні [2]

\begin{tabular}{|c|c|c|c|c|c|c|c|c|}
\hline \multirow[t]{2}{*}{ Соціальні індикатори (показники) } & \multirow[t]{2}{*}{2014} & \multirow[t]{2}{*}{2015} & \multirow[t]{2}{*}{2016} & \multirow[t]{2}{*}{2017} & \multirow[t]{2}{*}{2018} & \multirow[t]{2}{*}{2019} & \multicolumn{2}{|c|}{$\begin{array}{l}\text { Коефіцієнт } \\
\text { кореляції* }\end{array}$} \\
\hline & & & & & & & Ryx1 & Ryx2 \\
\hline $\begin{array}{c}\text { Коефіцієнт природного приросту } \\
\text { населення, на } 1000 \text { осіб. }\end{array}$ & $-3,9$ & $-4,2$ & $-4,4$ & $-5,1$ & $-6,1$ & $-6,6$ & 0,729 & 0,779 \\
\hline Сумарний коефіцієнт народжуваності & 1,498 & 1,506 & 1,466 & 1,374 & 1,301 & 1,228 & 0,686 & 0,757 \\
\hline Рівень безробіття, \% & 9,3 & 9,1 & 9,3 & 9,5 & 8,8 & 8,2 & 0,924 & 0,431 \\
\hline $\begin{array}{c}\text { Реальна заробітна плата, \% до поп. } \\
\text { року }\end{array}$ & 93,5 & 79,8 & 109,0 & 119,1 & 112,5 & 109,8 & 0,086 & $-0,772$ \\
\hline \begin{tabular}{|c|} 
Рівень бідності населення із \\
доходами у місяць, нижчими \\
фактичного прожиткового мінімуму, \%
\end{tabular} & 16,7 & 51,9 & 51,1 & 34,9 & 27,6 & 23,1 & 0,411 & $-0,145$ \\
\hline
\end{tabular}

Досить неоднозначно можна трактувати вплив обсягів фінансування соціальної сфери на рівень безробіття та реальної заробітної плати. Адже коефіцієнти кореляції демонструють, що збільшення соціальних видатків супроводжується збільшенням рівня безробіття та зниженням реальної заробітної плати. Це можна пояснити з одного боку поширенням утриманських настроїв в умовах отримання соціальних виплат, які для окремих категорій громадян відповідають їх мінімальним стандартам життя, а відтак призводять до безробіття. Щодо впливу на рівень реальної заробітної плати, то соціальні видатки певною мірою $€$ фактором зростання грошової маси в обігу, а відтак - інфляції, що обумовлює знецінення реальних доходів громадян.

Висновки. Протягом 2014-2020 рр. обсяги бюджетного фінансування соціальної сфери за всіма складовими (освіта, охорона 
здоров'я, духовний та фізичний розвиток, соціальний захист та забезпечення) постійно зростали. Попри невпинне зростання бюджетного фінансування видатків соціального призначення, все ж їх темпи не відповідали темпам інфляції, що свідчить про зниження фінансування соціальної сфери в реальному вираженні. Найбільшу значимість місцеві бюджети в Україні мають щодо фінансування освіти, а також духовного та фізичного розвитку, державний бюджет - щодо фінансування програм соціального захисту та забезпечення, тоді як практично однакова значимість різних рівнів бюджетної системи в Україні має місце щодо фінансування охорони здоров'я. Врахування видатків з фондів соціального страхування дещо змінює структурні особливості фінансування соціальних видатків в Україні: найбільша частка у сукупних видатках припадає на місцеві бюджети (близько $40 \%$ у 2019 р.), водночас на державний бюджет та фонди соціального страхування у 2019 р. припадало відповідно $32 \%$ та 28\% сукупних видатків. Тобто практично третина усіх видатків на соціальні цілі в Україні фінансується за рахунок страхових фондів. На основі порівняння загальних обсягів державного фінансування видатків соціального призначення в Україні та ЄС по відношенню до ВВП можна констатувати, що державна політика ЄС має вищий рівень соціальної спрямованості. Рівень соціальної безпеки в Україні за розрахунками Міністерства розвитку економіки, торгівлі та сільського господарства $\epsilon$ достатньо низьким (протягом 20102019 рр. варіював від 56 до 64\%). При цьому між обсягами фінансування соціальної сфери та інтегральним індексом соціальної безпеки наявний прямий зв'язок, тобто фінансування соціальних видатків $€$ фактором зростання соціальної безпеки. Показово, що 3 переважною більшістю показників, які $€$ складовими-індикаторами соціальної безпеки відповідно до національної методики, обсяги фінансування соціальних видатків наявності зв'язку не демонструють або ж він суперечить логіці. Це свідчить про те, що фінансування соціальної сфери чинить комплексний вплив на всі складові соціальної безпеки, який інколи проявляється через певний часовий лаг.

1.Бюджетна політика: дані та аналітика / Міністерство фінансів України. URL: https://www.mof.gov.ua/uk/budget-policy (дата звернення: 10.04.2021). 2. Демографічна та соціальна статистика: статистичні дані / Державна служба статистики України. URL: http://ukrstat.gov.ua (дата звернення: 21.04.2021). 3. Державні видатки за функціями. European statistics / Eurostat. URL: https://cutt.ly/OnEnbLJ (дата звернення: 21.04.2021). 4. Звіти щодо виконання державного бюджету України: попередні бюджети / Фіністерство фінансів України. URL: https://www.mof.gov.ua/uk/previous-years-budgets (дата звернення: 
20.04.2021). 5. Операції Пенсійного фонду України та фондів соціального страхування (без коштів з державного бюджету та взаємних розрахунків фондів) / Державна служба статистики України. http://ukrstat.gov.ua/imf/arhiv/opf/opf_u_.htm (дата звернення: 21.04.2021). 6. Соціальний захист населення України у 2019 році : статистичний збірник / Державна служба статистики України. http://www.ukrstat.gov.ua/druk/publicat/kat_u/2020/zb/07/zb_szn_2019.pdf (дата звернення: 28.04.2021).

\section{REFERENCES:}

1. Biudzhetna polityka: dani ta analityka / Ministerstvo finansiv Ukrainy. URL: https://www.mof.gov.ua/uk/budget-policy (data zvernennia: 10.04.2021). 2. Demohrafichna ta sotsialna statystyka: statystychni dani / Derzhavna sluzhba statystyky Ukrainy. URL: http://ukrstat.gov.ua (data zvernennia: 21.04.2021). 3. Derzhavni vydatky za funktsiiamy. European statistics / Eurostat. URL: https://cutt.ly/OnEnbLJ (data zvernennia: 21.04.2021). 4. Zvity shchodo vykonannia derzhavnoho biudzhetu Ukrainy: poperedni biudzhety / Finisterstvo finansiv Ukrainy. URL: https://www.mof.gov.ua/uk/previous-years-budgets (data zvernennia: 20.04.2021). 5. Operatsii Pensiinoho fondu Ukrainy ta fondiv sotsialnoho strakhuvannia (bez koshtiv z derzhavnoho biudzhetu ta vzaiemnykh rozrakhunkiv fondiv) / Derzhavna sluzhba statystyky Ukrainy. URL: http://ukrstat.gov.ua/imf/arhiv/opf/opf_u_.htm (data zvernennia: 21.04.2021). 6. Sotsialnyi zakhyst naselennia Ukrainy u 2019 rotsi : statystychnyi zbirnyk / Derzhavna sluzhba statystyky Ukrainy. URL: http://www.ukrstat.gov.ua/druk/publicat/kat_u/2020/zb/07/zb_szn_2019.pdf (data zvernennia: 28.04.2021).

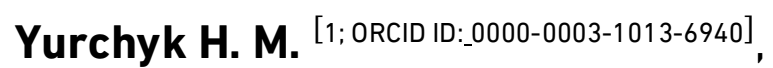
Candidate of Economics (Ph.D.), Associate Professor, Bilan S. A. ${ }^{[1 ; 0 R C I D ~ I D: 0000-0001-9814-5459], ~}$ Candidate of Pedagogical Sciences (Ph.D.), Associate Professor

${ }^{1}$ National University of Water and Environmental Engineering, Rivne

\section{SOCIAL EXPENDITURE IN UKRAINE: STRUCTURAL-DYNAMIC FEATURES OF FINANCING AND IMPACT ON SOCIAL SECURITY}

The purpose of this article is to study the structural and dynamic features of public funding of social expenditures in Ukraine in the context of their impact on social security. During 2014-2020, the amount of budget funding for the social sphere in all its components (education, health care, spiritual and physical development, social protection and security) has been constantly growing. Despite the steady growth of budget funding for social expenditures, their rates did not correspond to inflation, which indicates a decrease in funding for the social sphere in real terms. Local budgets in Ukraine are most important for financing education, as well as spiritual and physical development, the state budget is for financing social protection and security programs, while almost the same importance of different levels of the budget system in Ukraine is for financing health care. Taking into 
account expenditures from social insurance funds somewhat changes the structural features of financing social expenditures in Ukraine: the largest share in total expenditures falls on local budgets (about $40 \%$ in 2019), while the state budget and social insurance funds in 2019 , accounted for $32 \%$ and $28 \%$ of total expenditures, respectively. That is, almost a third of all social expenditures in Ukraine are financed by insurance funds. Based on a comparison of the total amount of public funding for social expenditures in Ukraine and the EU in relation to GDP, it can be stated that the EU public policy has a higher level of social orientation. The level of social security in Ukraine, according to the Ministry of Economic Development, Trade and Agriculture, is quite low (during 2010-2019 it varied from 56 to 64\%). At the same time, there is a direct link between the amount of funding for the social sphere and the integrated index of social security. That is, the financing of social expenditures is a factor in the growth of social security. It is noteworthy that with the vast majority of indicators that are components of indicators of social security in accordance with national methods, the amount of funding for social expenditures does not show the connection or it contradicts the logic. This indicates that the financing of the social sphere has a complex impact on all components of social security, which is sometimes manifested through a certain time lag.

Keywords: social expenditures; social security; social sphere; poverty; standard of living.

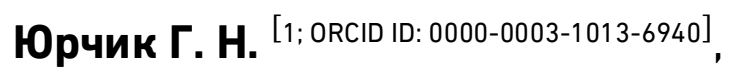
к.э.Н., доцент, Билан С. А. [1; ORCID ID: 0000-0001-9814-5459], к.п.н., доцент

${ }^{1}$ Национальный университет водного хозяйства и природопользования, г. Ровно

\section{СОЦИАЛЬНЫЕ РАСХОДЫ В УКРАИНЕ: СТРУКТУРНО- ДИНАМИЧЕСКИЕ ОСОБЕННОСТИ ФИНАНСИРОВАНИЯ И ВЛИЯНИЕ НА СОЦИАЛЬНУЮ БЕЗОПАСНОСТЬ}

Исследованы

структурно-динамические

особенности государственного финансирования расходов социального назначения в Украине. Выявлена значимость различных уровней бюджетной системы и отдельных источников В финансировании социальной сферы. Обосновано влияние расходов социального назначения на уровень социальной безопасности и его основные составляющие в Украине.

Ключевые слова: социальные расходы; социальная безопасность; социальная сфера; бедность; уровень жизни. 